\title{
\%utoctonía
}

Ciencias Sociales e Historia

\section{Inka History in Knots. Reading Khipus as Primary Sources by Gary Urton. University of Texas Press. Austin, 2017, 319 págs.}

This book is not just about khipus or Inka history. It is the history of an archive that Gary Urton has built during 25 years of study. This archive is an accurately classified corpus consisting of approximately 923 khipus, which are housed at different museums and collections across the world. In Urton's archive, each khipu has its own record number, and all of them have been summarized in a valuable catalogue included at the end of the book. Alongside with this index, there are two other catalogues of the largest khipu collections ever found in archaeological sites: 91 khipus from Pachacamac, and 29 khipus from Inkahuasi. The meticulous labor of organizing and cataloguing data provides a solid basis for Urton's research, and is one of the book's many merits.

The khipu archive systematized by Urton was once someone else's archive. It was part of the accounting files of an empire, an archive woven by khipukamayuqs who made drafts, copies and mistakes as any scribe would do. Some khipus actually had a "binding" made of drilled wooden bars, as we can see in those from the Ethnologisches Museum in Berlin. Others from Inkahuasi, for example, were linked together by a rope, as if they were in the same "folder." Knots have recto and verso, as the pages of any colonial file. One can imagine khipukamayuqs tying, untying, and re-tying knots in theirs cords, in the dynamic process of writing, erasing, and overwriting data.

In this sense, another great merit of the book is the visibility that Urton gives to khipukamayuqs, who played a key role in the daily life of Andean communities as political agents for the Inka state. If we consider the huge amount of information that they had to collect to fulfill the obligations of the decimal system that underlie Inka administration, then we must suppose that there was a large number of trained people, who shared

\footnotetext{
Inka History in Knots. Reading Khipus as Primary Sources by Gary Urton. University of Texas Press. Austin, 2017, 319

págs. Soledad González Díaz,

Autoctonía. Revista de Ciencias Sociales e Historia, Vol. I, N², Julio-Diciembre 2017, 300-302

ISSN 0719-8213

DOI: http://dx.doi.org/10.23854/autoc.v0i2.41
} 
accounting techniques and shaped the meaning of their cord accounts all along the Tawantinsuyu. The khipukamayuqs had to manage the different regional "knotting" traditions, and at the same time, the necessity of standardizing data to be intelligible at

multiple interconnected and hierarchical levels. This means that one single cord of a hypothetical imperial khipu --according to Urton not even one khipu has been found in the capital of Cuzco-- is the result of extremely coordinated work among many other khipukamayuqs.

Another merit of this book is that Urton took the khipus away from the museum's exhibitions, introducing them to the broader public, giving them an individual identity and a social life, as he did previously with his study of quechua numbers. Here khipus interact not just with the reader, but also with other khipus, and occasionally with written documents. Sometimes the information in both records --khipu and khipu or khipu and written documents-- match, and sometimes they simply do not do so. Because an important lesson from this book is that there are too many dead-ends in khipu research, and that on khipu account $2+2$ is not always 4 .

Urton is an always-present narrator that guides the reader through the arithmetic paradigms and numerical patterns that arise from khipu analysis. This is important because even though this book deals with math theory, most of its readers are anthropologists, historians, and archaeologists. The author bears this in mind, and therefore, in every chapter he summarizes the main arguments, and rehearses previous or later parts of the broader narrative when necessary. At the same time, he continuously reminds us of the fragmentary nature and interpretative conundrum that is involved in khipu research: $2+2$ is not always 4 , because the local data was collected with a considerable degree of flexibility, including "noise" or "fuzziness" in the act of accounting. In the official Inka level, instead, mathematical operations seem more accurate and regulated by the notion of an ideal account, expressed in decimals and rounding numbers.

Since the author constantly stresses the problems that arise from his proposal, the maincontributions of thisbookareformulated in a serious and honest way. For example, the calendricalvalues registered in a khipu coming from a chullpa in Laguna de los Cóndores match the census data from a close location contained in a document commissioned by encomendero Alonso de Alvarado in the 16th century, based on the information provided by a cacique named Guaman. Instead of focusing on the ownership of this khipu, Urton emphasizes how this piece of evidence can help us to understand the temporal pattern that underlies the organization of mit'a labor service in late Inka times (even though readers will likely remember this khipu as Guaman's khipu). There are other examples of the social life of khipus. Another khipu, also from Laguna de los Cóndores, seems to record the steady decline of population from Chachapoyas region during the late pre- 
Hispanic and early colonial times, at a rate that is very similar to that calculated by Inge Schjellerup in her demographic study for the same period. Another khipu belonging to the Radicati di Primeglio collection records data in six cord groups with a total value of 133 , while a colonial document from Santa valley from 1670 --the Padrón de indios tributarios recuayes: conchucos-- states that there were 132 tribute payers organized into six ayllus in San Pedro de Corongo.

As usual, in none of three aforementioned cases, the numbers match exactly. This fact takes us to the quest for the pipe-dream of Andean studies: the discovery of a "Rosetta khipu", one with its written transcription. Even if someday that "fabled couple" were to be found, a straightforward process of deciphering khipus would still not be possible, because khipus, in Urton's perspective, are not three dimensional cord versions of a writing system in which a sign denotes the sound of a language. Rather, they encode a semasiographic notation system, based on signs that convey meaning. So, his proposal is to work carefully with the available data encoded in administrative khipus, aiming to build for the first time an Inka history based on primary sources. Given the demographical and statistical nature of khipu information, Urton proposes that the best interpretation for them can be based on the historical school of the Annales, which rejected the prominence of the great-man in history, centering its interest in the social and economic structures that shaped social behavior (Should we really say goodbye to Manco Capac and Pachacuti?). This book is a first attempt in making an Inka history starting from its own structural and organizational principles.

Accepting Urton's proposal involves a huge challenge for Andeanists and more so for historians, trained in the calligraphic culture of documents and in the classic notion of a written archive. Doing so requires confronting a big obstacle: khipus are quite often treated as museum pieces or antiquities and not as primary sources or an archive. More interdisciplinary work is necessary in order to develop new methodologies to integrate the khipu corpus into historical research. Making digital reproductions, generating new ways of khipu transcriptions and encouraging interdisciplinary encounters, are key issues in the process of embarking on this challenging endeavor.

This book is required reading for everyone interested in khipus. It also deals with power, performance, missing links, pilgrims, plunders, discoveries, losses, and the personal memories of an anthropologist that, in his own perspective, undertook an "unexpected career." 